\title{
Involvement of the coeliac ganglion in the luteotrophic effect of androstenedione in late pregnant rats
}

\author{
Marilina Casais, Silvia Marcela Delgado, Zulema Sosa and Ana María Rastrilla \\ Laboratorio de Biología de la Reproducción (LABIR), Facultad de Química, Bioquímica y Farmacia, \\ Universidad Nacional de San Luis, Chacabuco 917 (5700), San Luis, Argentina
}

Correspondence should be addressed to A M Rastrilla; Email: amras@unsl.edu.ar, mcasais@unsl.edu.ar

\begin{abstract}
Using the ex vivo coeliac ganglion-superior ovarian nerve-ovary system at the end of pregnancy when luteal regression starts, we investigated whether, when administered systemically or when added directly to the ganglion compartment, androstenedione $\left(A_{2}\right)$ can reverse such regression, and whether the neural (noradrenaline (NA)) and endocrine ( $\left.A_{2}\right)$ joint action modifies the release of ovarian progesterone. The experimental groups were as follows: group $1-A_{2}$ injected systemically $48 \mathrm{~h}$ before incubation of the system $\left(A_{2}\right)_{s}$; group $2-A_{2}$ directly added to the ganglion compartment $\left(A_{2}\right)_{\text {gi }}$ group $3-A_{2}$ injected $48 \mathrm{~h}$ before incubation of the system with NA in the ganglion compartment $\left(A_{2}+N A\right)$; group $4-A_{2}$ plus NA added to the ganglion compartment $\left(\mathrm{NA}+\mathrm{A}_{2}\right)_{\mathrm{g}}$. The controls were ex vivo systems without treatment (control), and with the addition of NA alone in the ganglion compartment (NA). The results were as follows. For $\left(A_{2}\right)_{s}$ versus control, progesterone increased on days 19 and 21 of pregnancy at all the studied times and only at $180 \mathrm{~min}$ on day 20 . For $\left(A_{2}+N A\right)$ versus $\left(A_{2}\right)_{s}$, progesterone increased on days 19 and 21. For $\left(A_{2}+N A\right)$ versus $N A$, progesterone increased at all the studied times on days 19 and 21 and at $180 \mathrm{~min}$ on day 20 . For $\left(A_{2}\right)_{g}$ versus control, progesterone significantly increased every pregnancy day. For $\left(N A+A_{2}\right)_{g}$ versus $\left(A_{2}\right)_{g}$, progesterone decreased at 120 and $180 \mathrm{~min}$ on day 19. For (NA + $\left.A_{2}\right)_{g}$ versus $N A$, progesterone increased on days 20 and 21. We can conclude that $A_{2}$ can reverse the functional regression of the corpus luteum either systemically or, what is more surprising, when directly added to the coeliac ganglion, whose action on the ovary is exerted via superior ovarian nerve. Reproduction (2006) 131 361-368
\end{abstract}

\section{Introduction}

The coeliac ganglion, part of the sympathetic prevertebral chain, is constituted mainly by principal neurons and interneurons such as the peptidergic and the intensely fluorescent (SIF) (Eränkö 1978, Abe et al. 1983, Matthews 1989, Prud'Homme et al. 1999). The sympathetic ganglia possess a great variety of specific receptors and neurotransmitters, among them catecholamines (Klein \& Burden 1988), neuropeptides (Dalsgaard et al. 1983) and gaseous neurotransmitters such as nitric oxide (Morales et al. 1995). It is interesting to point out the presence of a profuse capillary plexus that constitutes a microcirculation among the different ganglionic structures (Chau \& Lu 1995).

Previous studies have shown that the humoral environment influences the functioning of the coeliac ganglion, thus affecting the ovary via the superior ovarian nerve (Aguado 2002).

The superior ovarian nerve is mostly constituted by adrenergic fibres whose origin neurons are mainly located in the coeliac ganglion (Baljet \& Drukker 1979) and whose terminals act directly upon the secretory part of the ovary, including the theca externa and interna of the follicle, the corpus luteum capsule and the interstitial gland. However, direct contact of nerves with luteal and granulosa cells has not been shown (Lawrence \& Burden 1980, Erickson et al. 1985, Klein \& Burden 1988). The ovarian noradrenergic stimulation affects progesterone secretion and its synthesis by an increase of cytochrome P450scc and $3 \beta-H S D$ enzymatic activity. In corpus luteum, this effect is mediated via $\beta_{1}$ and $\beta_{2}$ receptors (Pesta et al. 1994, Miszkiel \& Kotwica 2001) with activation of cAMP (Lefkowitz, 1987). Besides acting on the luteal $\beta$-receptors, noradrenaline (NA) acts on ovarian vascular adrenoreceptors (Reynolds \& Ford 1984) and adipose cell $\beta$-receptors. The stimulation of lipolysis and the increased blood flow through the ovary could supply the corpus luteum with serum-derived lipoproteins as a source of cholesterol for luteal steroidogenesis (Williams 1989). In studies in conscious heifers, the infusion of NA into the abdominalis aorta stimulated the secretion of progesterone within a few minutes in a dose-dependent manner (Kotwica et al. 2002). De Bortoli et al. (1998, 
2000) demonstrated that a central adrenergic stimulus produces acute effects on the release of steroids from the ovary. Ovarian progesterone changes could be attributed to signals coming from ganglionic neurons, which are affected by the central adrenergic stimulation. By use of the ex vivo coeliac ganglion-superior ovarian nerve-ovary system (coeliac ganglion-SON-ovary) of rats in the second half of pregnancy, the release of ovarian progesterone was modified at 30 min of incubation with NA in the ganglion compartment (Casais et al. 2001). This rapid ovary response was probably the result not only of a direct influence of NA on the luteal cells via $\beta$-receptors, but also of other factors released via SON which could amplify this effect indirectly.

It is already known that progesterone is a survival factor in the corpora lutea (Sugino et al. 1997, Tellería et al. 1999, Villavicencio et al. 2002). At the end of pregnancy, the corpora lutea suffer a regression process that decreases their capacity to produce progesterone (functional regression) and causes the subsequent involution of the luteal tissue, including steroidogenic and nonsteroidogenic cells (structural regression) (Bowen-Shauver \& Tellería 2003).

On the other hand, androstenedione $\left(\mathrm{A}_{2}\right)$, the principal androgen in rat, has a well-known antiapoptotic affect either through its intraluteal conversion to oestradiol (Gibori et al. 1988) or through a non-genomic mechanism (Carrizo et al. 1994, Thordarson et al. 1997, Machelón et al. 1998). It has also been suggested that $A_{2}$ could have a dual effect: a non-genomic effect that would lead to the activation of a complex cascade of signal transduction (Cato \& Peterziel 1998) and a subsequent genomic event.

With these antecedents, we thought it interesting to investigate whether $A_{2}$ is capable of reversing the luteal functional regression, whether systemically administered (by injection $48 \mathrm{~h}$ before the system incubation) or directly added to the ganglion compartment.

Considering that NA action in the ganglion compartment decreases as pregnancy progresses (Casais et al. 2001) and that $A_{2}$ inhibits the luteal functional regression, we also decided to analyse the neural and endocrine joint action of $\mathrm{NA}$ and $\mathrm{A}_{2}$ on the release of ovarian progesterone at the end of rat pregnancy.

\section{Materials and Methods}

\section{Animals}

Adult female rats bred in our laboratory (originally Holtzman albino strain) aged 2-3 months and weighing $220 \pm 50 \mathrm{~g}$ were used. The rats were housed under controlled light (lights on from 0700 to $1900 \mathrm{~h}$ ) and temperature $\left(24 \pm 2{ }^{\circ} \mathrm{C}\right)$ conditions, and allowed ad libitum access to water and food (rat chow-Cargil SACI; Saladillo, Buenos Aires, Argentina).

To induce pregnancy, female rats were caged individually with fertile males beginning on the afternoon of prooestrus. Positive mating was verified on the following morning by identifying sperm or copulation plugs in the vagina. This day was designated as day 0 of pregnancy. In our laboratory, rats usually give birth on day 22 .

Animals were handled according to the procedures approved in the UFAW Handbook on the Care and Management of Laboratory Animals, vol. 1: Terrestrial Vertebrates (7th edn), edited by T Poole (1999), and the Guide for Animal Use and Handling of the National University of San Luis.

\section{Systemic $A_{2}$}

$\mathrm{A}_{2}$ was systematically administered $48 \mathrm{~h}$ before the incubation of coeliac ganglion-SON-ovary system with and without addition of NA in the ganglion compartment.

\section{Drugs}

Drugs used were:

- hydrochloride of L-D-NA (Sigma)

- 4-androsteno-3,17, diona $\left(\mathrm{A}_{2}\right)$ (Sigma).

\section{$A_{2}$ preparation for injection}

$\mathrm{A}_{2}$ was dissolved in benzilic alcohol (2-5\% of the final volume) to a sufficient concentration to inject each animal with $10 \mathrm{mg} \mathrm{A}_{2} / 0.2 \mathrm{ml}$ vegetable oil. The administration to animals was subcutaneous (s.c.).

\section{Procedure}

Groups of six animals each on days 17-19 of pregnancy were used for each experimental procedure with the following distribution:

- group 1: pregnant rats on day 17

- group 2: pregnant rats on day 18

- group 3: pregnant rats on day 19.

Rats were administered (s.c.) $10 \mathrm{mg} \mathrm{A}_{2} / 0.2 \mathrm{ml}$ oil vehicle. This procedure was carried out at $0900 \mathrm{~h}$ on the pregnancy days mentioned (days 17-19). The animals were caged individually, and, at $0900 \mathrm{~h}$ on days 19-21 of pregnancy, that is to say, $48 \mathrm{~h}$ after injecting $A_{2}$, they were anaesthetized under ether bell, and the coeliac ganglion-SON-ovary system was immediately extracted (Casais et al. 2001).

The fetuses were removed and killed under ether anaesthesia. Briefly, the coeliac ganglion-SON-ovary system was placed in a cuvette with two compartments, each containing $2 \mathrm{ml}$ Krebs-Ringer bicarbonate buffer, pH 7.4; $0.1 \mathrm{mg}$ gluco$\mathrm{se} / \mathrm{ml}$; and $0.1 \mathrm{mg}$ albumin $/ \mathrm{ml}$. After 30-min preincubation, the liquid was removed from the cuvette, buffer was added to the ovarian compartment, and buffer plus $0.1 \mathrm{mg}$ ascorbic $\mathrm{acid} / \mathrm{ml}$ was added to the ganglion compartment. The previous description corresponds to the group $\left(\mathrm{A}_{2}\right)_{\mathrm{s}}$. Previous injection of $\mathrm{A}_{2}$ plus $10^{-6} \mathrm{~mol} \mathrm{NA} / \mathrm{l}$ in the ganglion compartment constituted the group $\left(A_{2}+N A\right)$. 
Periodic extractions of incubation liquid were made from the ovary $(250 \mu \mathrm{l})$ at 30, 60, 120 and $180 \mathrm{~min}$, and they were stored in a freezer at $-20^{\circ} \mathrm{C}$ until the determination of progesterone by RIA. The corresponding corrections were made in all cases, taking into consideration the volume extracted in each tested period.

\section{$A_{2}$ in coeliac ganglion}

The coeliac ganglion-SON-ovary system was incubated in the presence of $\mathrm{A}_{2}$ with or without the addition of $\mathrm{NA}$ to the ganglion compartment.

\section{$10^{-6} \mathrm{~mol} \mathrm{~A}_{2} / \mathrm{l}$ preparation}

$A_{2}$ was dissolved in benzilic alcohol $(2-5 \%$ of the final volume), and a solution at final concentration of $10^{-6} \mathrm{~mol}$ $\mathrm{A}_{2} / \mathrm{l}$ in Krebs-Ringer bicarbonate buffer, $\mathrm{pH} 7.4 ; 0.1 \mathrm{mg}$ glucose $/ \mathrm{ml}$; and $0.1 \mathrm{mg}$ albumin/ml was added directly to the ganglion compartment. This solution was used for group $\left(A_{2}\right)_{g}$.

The solution ( $\left.\mathrm{NA}+\mathrm{A}_{2}\right)_{\mathrm{g}}$ was prepared in such a way that the joint preparation of $\mathrm{NA}$ and $\mathrm{A}_{2}$ constituted a solution with final concentration of $10^{-6} \mathrm{~mol} \mathrm{NA}+\mathrm{A}_{2} / \mathrm{l}$ in KrebsRinger bicarbonate buffer, $\mathrm{pH} 7.4 ; 0.1 \mathrm{mg}$ glucose/ml; and $0.1 \mathrm{mg}$ albumin $/ \mathrm{ml}$. This solution was directly added to the ganglion compartment.

\section{Procedure}

Rats on days 19-21 of pregnancy were anaesthetized under ether bell, and the coeliac ganglion-SON-ovary system was extracted by the procedure previously described. The addition of $10^{-6} \mathrm{~mol} \mathrm{~A}_{2} / \mathrm{l}$ plus $0.1 \mathrm{mg}$ ascorbic acid $/ \mathrm{ml}$ to the ganglion compartment characterized group $\left(\mathrm{A}_{2}\right)_{\mathrm{g}}$. Group $\left(\mathrm{NA}+\mathrm{A}_{2}\right)_{\mathrm{g}}$ had $10^{-6} \mathrm{~mol}$ $\mathrm{NA}+\mathrm{A}_{2} / \mathrm{l}$ plus $0.1 \mathrm{mg}$ ascorbic acid/ml in the ganglion compartment. Progesterone determination in the ovarian incubation liquid was measured by RIA at all the studied times.

\section{Progesterone assay}

Progesterone was measured by RIA using antiserum raised against progesterone-11-BSA conjugate in rabbits, provided by $\operatorname{Dr} R$ P Deis (Laboratorio de Reproducción y Lactancia Mendoza, Argentina). The sensitivity, variability and cross-reaction of this RIA have been reported previously (Bussmann \& Deis 1979). The sensitivity of the assay is less than $5 \mathrm{ng}$ progesterone/ml serum, and the inter- and intra-assay coefficients of variation were less than $10 \%$. This assay has been previously validated (Bussmann \& Deis 1979).

\section{Statistical analysis}

Results are presented as mean \pm S.E.M. in each group of six rats. Differences between two groups were analysed with Student's $t$-test. The analysis of the variance (ANOVA I), followed by Duncan's multiple-range test was used for several comparisons. A value of $P<0.05$ was considered statistically significant (Snedecor \& Cochran 1976).

\section{Results}

\section{Systemic effect of $A_{2}$ on the release of ovarian progesterone in the coeliac ganglion-SON-ovary system}

Figure $1 \mathrm{~A}-\mathrm{C}$ shows that in the coeliac ganglionSON-ovary system extracted from animals on days 19 and 21 of pregnancy, with previous s.c. administration (48 h) of $10 \mathrm{mg} A_{2} / 0.2 \mathrm{ml}$ oil vehicle $\left(A_{2}\right)_{s}$, the levels of progesterone increased significantly when compared with the control values at all the studied times $(* P<0.05)$. On day 20, a decrease at 30 and $60 \mathrm{~min}(0.06 \pm 0.008$ compared with $0.13 \pm 0.02 \mathrm{ng} / \mathrm{mg}$ ovary, $* P<0.05$; $0.08 \pm 0.018$ compared with $0.17 \pm 0.03 \mathrm{ng} / \mathrm{mg}$ ovary, $* P<0.05$ respectively) and an increase at $180 \mathrm{~min}$ $(0.26 \pm 0.02$ compared with $0.18 \pm 0.03 \mathrm{ng} / \mathrm{mg}$ ovary, $* P<0.05)$ were observed in relation to control values. The comparison was done with the control rats without treatment since the s.c. administration of $0.2 \mathrm{ml}$ oil vehicle alone did not modify the release of progesterone (data not shown).

When we added $10^{-6} \mathrm{~mol} \mathrm{NA} / \mathrm{l}$ to the ganglion compartment $\left(\mathrm{A}_{2}+\mathrm{NA}\right)$ besides injecting $10 \mathrm{mg} \mathrm{A}_{2} / 0.2 \mathrm{ml}$ oil vehicle, $48 \mathrm{~h}$ before the incubation of the coeliac ganglion-SON-ovary system, the release of progesterone on day 19 increased significantly in relation to $\left(A_{2}\right)_{s}$ at all the studied times $(\bullet P<0.05)$. On day 20 , a decrease of progesterone was observed only at $120 \mathrm{~min}(0.09 \pm 0.03$ compared with $0.17 \pm 0.03 \mathrm{ng} / \mathrm{mg}$ ovary, $\bullet P<0.05)$, and on day 21 , there was a significant increase of progesterone at 60 and $180 \mathrm{~min}(0.21 \pm 0.03$ compared with $0.09 \pm 0.016 \mathrm{ng} / \mathrm{mg} \quad$ ovary, $\bullet P<0.01 ; \quad 0.24 \pm 0.04$ compared with $0.13 \pm 0.01 \mathrm{ng} / \mathrm{mg}$ ovary, $\bullet P<0.01$ respectively).

When we compared the experimental groups $\left(A_{2}+N A\right)$ in relation to the stimulation of coeliac ganglion with $10^{-6} \mathrm{~mol} \mathrm{NA} / \mathrm{l}$, it was observed that the neural and endocrine joint action increased the release of progesterone on days 19 and 21 at all the studied times ( $\#<<0.05)$, and on day 20 only at $180 \mathrm{~min}(0.24 \pm 0.03$ compared with $0.10 \pm 0.005 \mathrm{ng} / \mathrm{mg}$ ovary, $\# P<0.01)$.

\section{Ganglionic effect of $\mathrm{A}_{2}$ in the coeliac ganglion-SON- ovary system on the release of ovarian progesterone}

Figure $2 \mathrm{~A}-\mathrm{C}$ shows that the presence of $10^{-6} \mathrm{~mol}_{2} / \mathrm{l}$ in coeliac ganglion $\left(A_{2}\right)_{g}$ increased the release of progesterone in relation to the control at all the studied times on the days of pregnancy studied (days 19-21) $(* P<0.01)$.

The analysis of $\mathrm{NA}$ and $\mathrm{A}_{2}$ joint action in the coeliac ganglion $\left(\mathrm{NA}+\mathrm{A}_{2}\right)_{\mathrm{g}}$ shows that the release of ovarian progesterone tends to decrease in relation to the sole action of $\left(\mathrm{A}_{2}\right)_{\mathrm{g}}$. On day 19 of pregnancy, the 

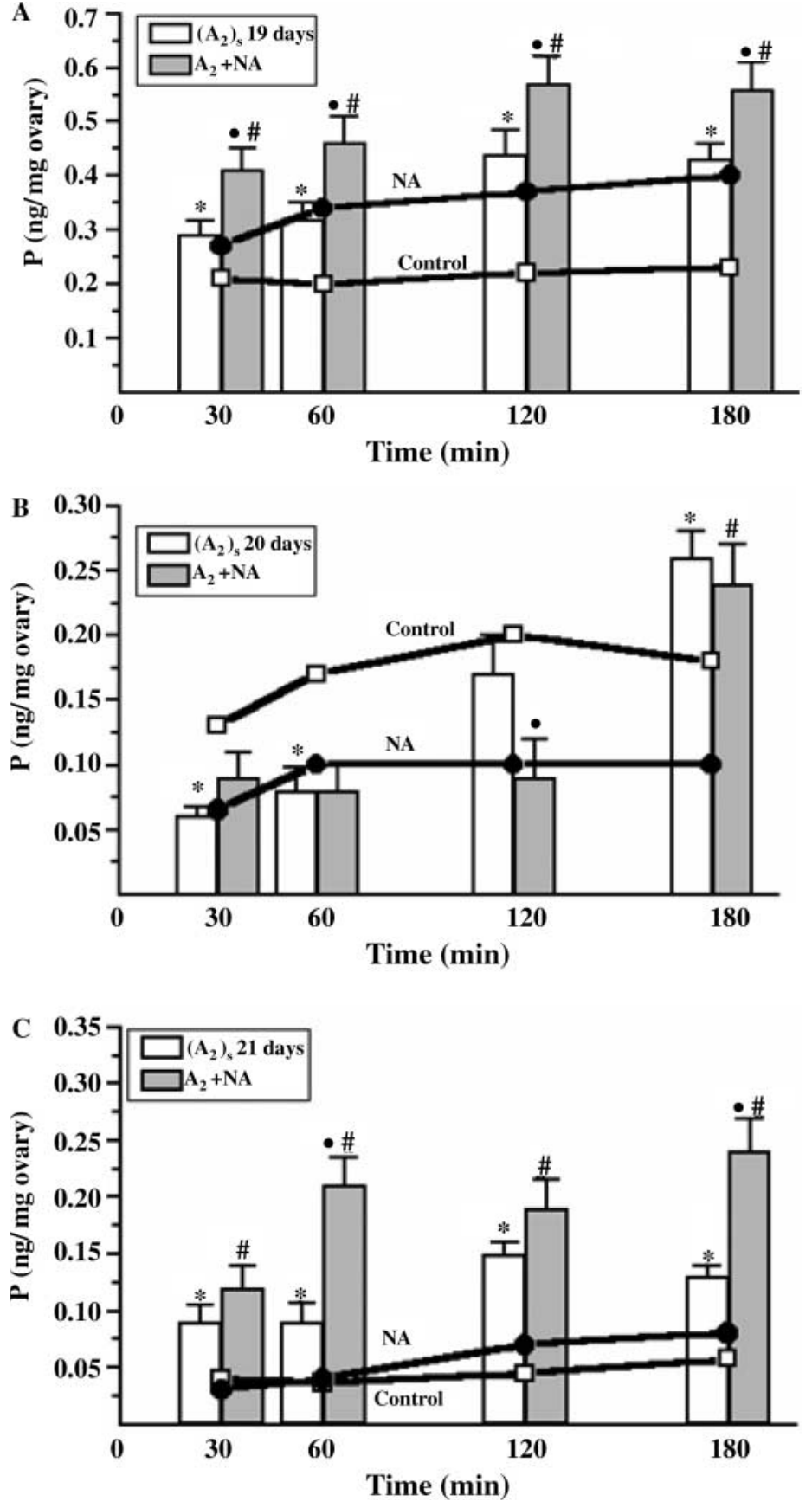

Figure 1 Effect of $A_{2}$ injection $48 \mathrm{~h}$ before, and subsequent incubation of the coeliac ganglion-superior ovarian nerve-ovary system with NA in the ganglion compartment, on the release of ovarian progesterone. The work was carried out with rats on days 19 (A), 20 (B) and 21 (C) of pregnancy. $\left(A_{2}\right)_{s}\left(A_{2}\right.$ injection, $10 \mathrm{mg} A_{2} / 0.2 \mathrm{ml}$ by rat, s.c., $48 \mathrm{~h}$ before and incubation of the coeliac ganglionSON-ovary system with Krebs-Ringer bicarbonate buffer, plus $0.1 \mathrm{mg}$ ascorbic acid/ml, at $37^{\circ} \mathrm{C}$ in an atmosphere of $95 \% \mathrm{O}_{2}-5 \% \mathrm{CO}_{2}$ for $180 \mathrm{~min}$ ). $\mathrm{A}_{2}+\mathrm{NA}\left(\mathrm{A}_{2}\right.$ injection, $10 \mathrm{mg} \mathrm{A}_{2} / 0.2 \mathrm{ml}$ by rat, s.c., $48 \mathrm{~h}$ and incubation of the coeliac ganglion-SONovary system with $10^{-6} \mathrm{~mol} \mathrm{NA} / 1$ in the ganglion compartment. Control (incubation with buffer alone of the coeliac ganglion-superior ovarian nerve-ovary system obtained from animals without previous $\mathrm{A}_{2}$ injection). NA (incubation of the coeliac ganglion-superior ovarian nerve-ovary system obtained from animals without previous $\mathrm{A}_{2}$ injection and with $10^{-6} \mathrm{~mol} \mathrm{NA} / 1$ in the ganglion compartment). Control and NA (Casais et al. 2001). Results are expressed as mean \pm S.E.M. of six animals per experimental group (ANOVA I and Duncan test of multiple range) $P<0.05$ and $P<0.01$. $\left(\mathrm{A}_{2}\right)_{\mathrm{s}}$ versus control $(*) ;\left(\mathrm{A}_{2}\right)_{\mathrm{s}}$ versus $\mathrm{A}_{2}+\mathrm{NA}(\bullet)$; $A_{2}+N A$ versus NA (\#). inhibition of the release of progesterone was significant at 120 and $180 \mathrm{~min}$ (120 min: $0.32 \pm 0.05$ compared with $0.58 \pm 0.06 \mathrm{ng} / \mathrm{mg}$ ovary, $\bullet P<0.01 ; 180 \mathrm{~min}$ : $0.30 \pm 0.03$ compared with $0.55 \pm 0.05 \mathrm{ng} / \mathrm{mg}$ ovary, - $P<0.01)$; on day 20, at $60 \mathrm{~min}(0.29 \pm 0.03$ compared with $0.40 \pm 0.03 \mathrm{ng} / \mathrm{mg}$ ovary, $\bullet P<0.05)$; and on day 21 , at $120 \mathrm{~min}(0.15 \pm 0.015$ compared with $0.21 \pm 0.016 \mathrm{ng} / \mathrm{mg}$ ovary, $\bullet P<0.05)$.

Finally, when comparing the experimental groups $\left(\mathrm{NA}+\mathrm{A}_{2}\right)_{\mathrm{g}}$ in relation to the stimulation of coeliac ganglion with $10^{-6} \mathrm{~mol} \mathrm{NA} /$, we observed that, through the neural and endocrine joint action, the release of progesterone did not exhibit significant changes on day 19, whereas on days 20 and 21, it increased significantly at all the studied times $(\# P<0.01)$.

\section{Discussion}

As stated in the introduction, this work demonstrates that $\mathrm{A}_{2}$ might act through an endocrine pathway and, surprisingly, through a neural pathway, since it reverses the functional regression of the corpus luteum either systemically 

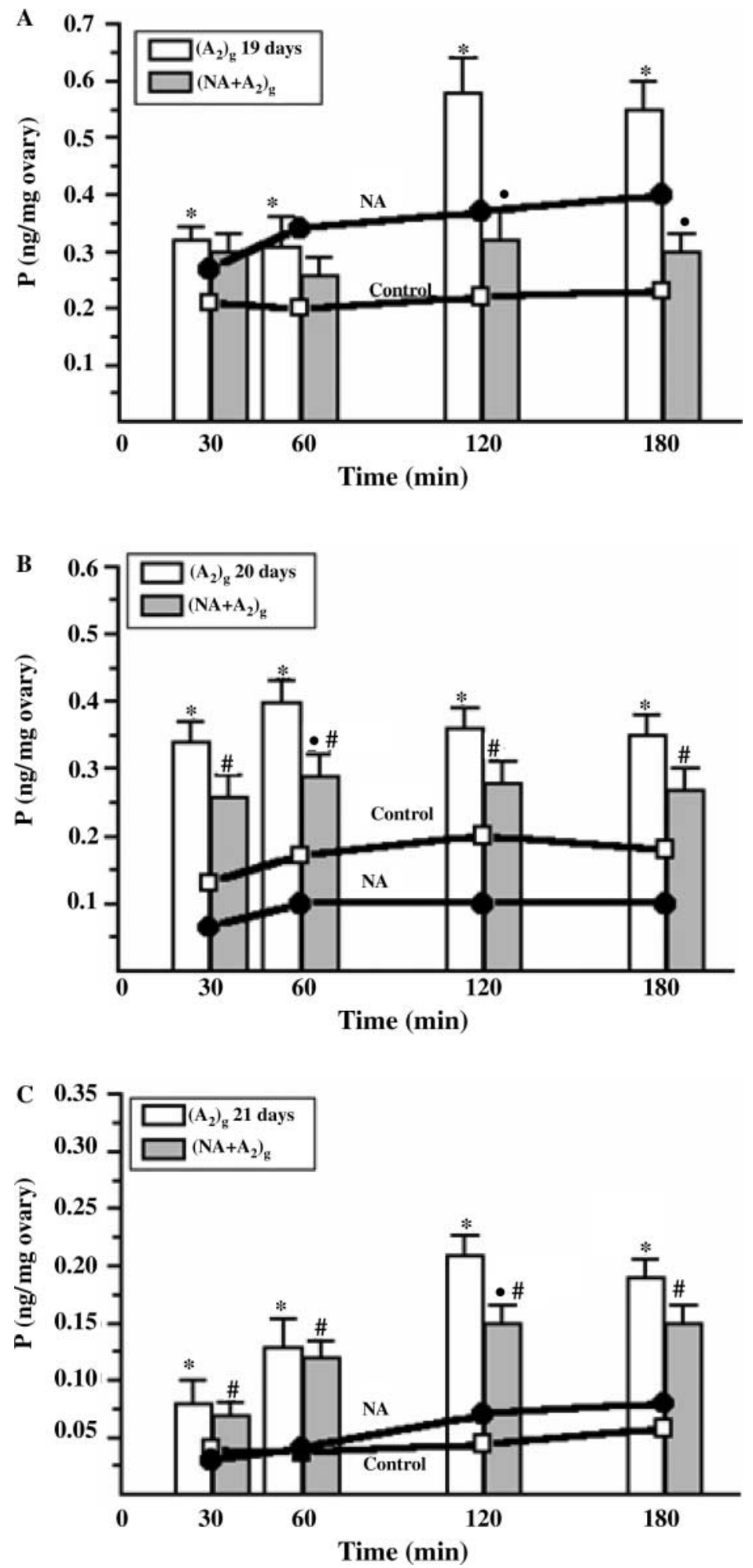

Figure 2 Effect of the incubation of the coeliac ganglion-superior ovarian nerve-ovary system in the presence of $\mathrm{NA}+\mathrm{A}_{2}$ in the ganglion compartment on the release of ovarian progesterone. The work was carried out with rats on days 19 (A), 20 (B) and 21 (C) of pregnancy. When the coeliac ganglionSON-ovary system is incubated with $10^{-6} \mathrm{~mol} \mathrm{~A}_{2} / \mathrm{l}$ in the coeliac ganglion, the group is $\left(\mathrm{A}_{2}\right)_{\mathrm{g}}$. When $\mathrm{A}_{2}$ and $\mathrm{NA}$, in $10^{-6} \mathrm{~mol} \mathrm{NA}+\mathrm{A}_{2} / \mathrm{l}$ are added together on the coeliac ganglion, the group is considered $\left(\mathrm{NA}+\mathrm{A}_{2}\right)_{\mathrm{g}}$. Control (incubation of the coeliac ganglion-superior ovarian nerve-ovary system with buffer). NA (incubation of the coeliac ganglion-superior ovarian nerve-ovary system, with $10^{-6} \mathrm{~mol} N \mathrm{NA} 1$ alone in the ganglion compartment). Control and NA (Casais et al. 2001). Results are expressed as mean \pm S.E.M. of six animals per experimental group (ANOVA I and Duncan test of multiple range) $P<0.05$ and $P<0.01$. $\left(\mathrm{A}_{2}\right)_{\mathrm{g}}$ versus control $(*) ;\left(\mathrm{A}_{2}\right)_{\mathrm{g}}$ versus $\left(\mathrm{NA}+\mathrm{A}_{2}\right)_{\mathrm{g}}(\bullet) ;\left(\mathrm{NA}+\mathrm{A}_{2}\right)_{\mathrm{g}}$ versus NA (\#). or when added to the ganglion compartment. On the other hand, the NA and $A_{2}$ joint action is greater when $A_{2}$ is administered $48 \mathrm{~h}$ before incubation. Its luteotrophic effect is likely to permit the rescue of the corpora lutea from regression. Consequently, NA action in the ganglion might be more effective.
Although $\mathrm{A}_{2}$ is a weak androgen, it is the androgen of highest concentration in the circulation in rat (Gibori et al. 1988). Previous research has demonstrated that $A_{2}$ stimulates the luteal production of progesterone in rodents (Carrizo et al. 1994, Tellería et al. 1995, Thordarson et al. 1997). It has also been demonstrated that $A_{2}$ interferes with 
luteal regression by inhibiting apoptosis and stimulating progesterone production (Goyeneche et al. 2002).

$\mathrm{A}_{2}$ acts at two distinct levels: through the nuclear receptor expression (Goyeneche et al. 2002) and through a non-genomic mechanism, as it occurs in the human luteinized granulosa cells, in which this androgen specifically modifies the intracellular levels of calcium. This effect could not be either imitated with testosterone or blocked by androgen receptor blockers (Machelón et al. 1998).

When working with the coeliac ganglion-SON-ovary system of late-pregnancy rats with and without previous $A_{2}$ injection $48 \mathrm{~h}$ before (systemic $A_{2}$ effect), we observed that the presence of $A_{2}$ in circulation increased the release of progesterone in the ovarian compartment, leading us to conclude that $A_{2}$ shows trophic effect. This agrees with the previously mentioned findings.

Besides, as the coeliac ganglion-SON-ovary system offers the ability to analyse neuroendocrine effects (Sosa et al. 2000, 2004, Casais et al. 2001, Delgado et al. 2004), we incubated ex vivo coeliac ganglion-SON-ovary systems extracted from animals with previous $\mathrm{A}_{2}$ injection in the presence of NA in the ganglion compartment, and we determined the levels of ovarian progesterone release. The presence of catecholamine in the coeliac ganglion increased ovarian progesterone not only in relation to $A_{2}$ injection but also when NA was added to the coeliac ganglion without previous $\mathrm{A}_{2}$ injection, leading us to suggest that $A_{2}$ may prevent regression of the corpus luteum.

These results agree with our previous work (Casais et al. 2001) in which we demonstrated that the adrenergic agents in the coeliac ganglion assist gestation physiology; that is, they decrease the release of ovarian progesterone at the end of pregnancy. However, when $\mathrm{A}_{2}$ is present in the circulation, NA in the coeliac ganglion has an effect in late pregnancy (especially on day 21), indicating that androgen has kept the biosynthetic structure of progesterone at ovarian level. Yet, under these experimental conditions, it is not possible to determine whether $A_{2}$ exerts its effects at ovarian or neural level.

There is an extensive literature about the action of gonadal steroids on the central nervous system (McEwen 1981, McEwen \& Alves 1999, Woolley 1999, Hammond et al. 2001). However, few studies have been devoted to the action of gonadal steroids on the peripheral nervous system. Gejman and Cardinali (1983) suggest that muscarinic cholinergic neurotransmission in bovine and rat superior cervical ganglia may be affected by hormones.

In their review, Papka and Mowa (2003) show the presence of oestrogen receptors in spinal cord neurons and sensory and autonomic ganglionic neurons in sites that are associated with innervation of the female reproductive organs, and explain the role that oestrogen may play in these neurons and their circuits. On the other hand, Chen and Hua (1987) have shown the fast effect of glucocorticoid on neuronal membrane of hippocampal slices of rat and isolated coeliac ganglion of guinea pig. Hua and
Chen (1989) also suggest that glucocorticoid can act nongenomically through its neuronal membrane receptor.

It is also known that the androgens can increase the volume, neuron number and synapses of developing rat superior cervical ganglion (Wright et al. 1991). Moreover, Félix et al. (2001) have shown an effect of testosterone on the electrical properties and nicotinic transmission of the major pelvic and coeliac ganglion neurons (nongenomic effect). The steroids are known to act through the steroid receptor and activate genomic pathways. Alternatives to the classical theory are theories of the non-genomic mechanisms, of which the hypothesis of membrane receptormediated effects in neurons is very important since rapid membrane effects form the basis of neuronal function.

Considering that a profuse fenestrate capilaris plexus has been described in the structure of prevertebral ganglia (Chau \& Lu 1995), it is reasonable to suggest that $A_{2}$ injected systemically reaches the ganglionic cells through the plexus. Aguado (2002) demonstrates that addition of serum to ganglion compartment in the coeliac ganglion$\mathrm{SON}$-ovary system increases the release of progesterone. These in vitro results support the idea that, in vivo, the humoral environment is highly influential on the functioning of the coeliac ganglion, thus affecting the ovary by a neural pathway.

When the direct ganglionic effect of $\mathrm{A}_{2}$ was analysed in the coeliac ganglion-SON-ovary system, the results were highly surprising. The levels of progesterone obtained by the application of $\mathrm{A}_{2}$ to the coeliac ganglion in relation to the controls were significantly higher on all the analysed days, and on day 21 they took longer (120-180 min) to reach the control levels of day 19 . This would clearly demonstrate the neural action of the androgen in preventing the functional regression of the corpus luteum. We also compared the effect of androgen on the coeliac ganglion in relation to the addition of NA to the ganglion compartment (Casais et al. 2001), and we observed that the levels of release of progesterone with $A_{2}$ in the coeliac ganglion were higher than those obtained with the addition of NA to the ganglion compartment on all the pregnancy days analysed. This action is more effective as the pregnancy age progresses. These facts support the idea that the steroid in the coeliac ganglion exerts a strong luteotrophic effect differently from the catecholamines that play an important role in the physiology of pregnancy and the subsequent delivery (Casais et al. 2001). Finally, in the analysis of the neural and endocrine joint effect of $\mathrm{NA}$ and $\mathrm{A}_{2}$ on the ganglion, a constant significant decrease in the release of ovarian progesterone was observed compared with $\mathrm{A}_{2}$ alone. Although NA in the ganglion tends to diminish the luteotrophic effect of $A_{2}$, it is evident that the action of $\mathrm{A}_{2}$ prevails. Future study of apoptosis at ovarian level should be developed to explain the molecular mechanism of ganglionic $\mathrm{A}_{2}$ action. 


\section{Acknowledgements}

This paper is dedicated to the memory of Luis I Aguado, PhD (1946-2003). We thank R P Deis, PhD, who provided the progesterone and $\mathrm{A}_{2}$ antiserums; $C \mathrm{M}$ Tellería, $\mathrm{PhD}$, for critical revision of the manuscript; and Eng. Mario Baudino for his informatic assistance. We also acknowledge the technical assistance of Luis Villegas. This work was supported by Grant 3711/92 from CONICET (Consejo Nacional de Investigaciones Científicas y Técnicas, Argentina) and by Grant 9302 from Universidad Nacional de San Luis, Argentina. This work is part of the doctoral thesis of Marilina Casais. The authors declare that there is no conflict of interest that would prejudice the impartiality of this scientific work.

\section{References}

Abe HH, Watanabe TY \& Yamamoto T 1983 Relationship between granule-containing cells and blood vessels in the rat autonomic ganglia. Anatomic Records 205 65-69.

Aguado LI 2002 Role of the central and peripheral nervous system in the ovarian function. Microscopic Research and Technique 59 $462-467$.

Baljet B \& Drukker J 1979 The extrinsic innervation of the abdominal organs in the female rat. Acta Anatomica $104243-267$.

Bowen-Shauver JM \& Tellería CM 2003 Luteal regression: a redefinition of the terms. Reproductive Biology and Endocrinology 1 $28-31$.

Bussmann LE \& Deis RP 1979 Studies concerning the hormonal induction of lactogenesis by prostaglandin $\mathrm{F}_{2 \alpha}$ in pregnant rats. Journal of Steroid Biochemistry and Molecular Biology 11 1485-1489.

Carrizo D, Rastrilla A, Tellería C \& Aguado L 1994 Androstenedione stimulates progesterone production in corpora lutea of pregnant rats: an effect not mediated by oestrogen. Journal of Steroid Biochemistry and Molecular Biology 51 191-197.

Casais M, Sosa ZY, Rastrilla AM \& Aguado LI 2001 Coeliac ganglion adrenergic activity modifies ovarian progesterone during pregnancy: its inter-relationship with LH. Journal of Endocrinology $\mathbf{1 7 0}$ 575-584.

Cato A \& Peterziel H 1998 The androgen receptor as mediator of gene expression and signal transduction pathways. Trends in Endocrinology and Metabolism 9 150-154.

Chau YP \& Lu KS 1995 Investigation of the blood-ganglion barrier properties in rat sympathetic ganglia by using lanthanum ion and horseradish peroxidase as tracers. Acta Anatomica (Basel) 153 135-144.

Chen YZ \& Hua SY 1987 Glucocorticoid's fast effects on neuronal membrane of hippocampal slices of rat and isolated coeliac ganglion of guinea-pig. Neuroscience 22s Suppl 336 [abstract].

Dalsgaard CJ, Baokelt T, Schultzberg M, Lundberg JM, Terenius L, Dockray GJ \& Goldstein M 1983 Origin of peptide-containing fibres in the inferior mesenteric ganglion of the guinea-pig: immunohistochemical studies with antisera to substance $\mathrm{P}$, enkephalin, vasoactive intestinal polypeptide, cholecystokinin and bombesin. Neuroscience 9 191-211.

De Bortoli MA, Garraza MH \& Aguado LI 1998 Adrenergic intracerebroventricular stimulation affects progesterone concentration in the ovarian vein of the rat: participation of the superior ovarian nerve. Journal of Endocrinology 159 61-68.

De Bortoli MA, Garraza MH \& Aguado LI 2000 Epinephrine intracerebroventricular stimulation modifies the LH effect on ovarian progesterone and androstenedione release. Journal of Steroid Biochemistry and Molecular Biology 74 19-24.

Delgado SM, Sosa Z, Dominguez NS, Casais M, Aguado LI \& Rastrilla AM 2004 Effect of the relation between neural cholinergic action and nitric oxide on ovarian steroidogenesis in prepubertal rats. Journal of Steroid Biochemistry and Molecular Biology 91 139-145.

Eränkö O 1978 Small intensely fluorescent (SIF) cells and neurotransmission in sympathetic ganglia. Annual Review of Pharmacology and Toxicology 18 417-421.

Erickson GF, Magofin DA, Dyer CA \& Hofeditz C 1985 The ovarian androgen producing cell: a review of structure/function relationships. Endocrinology Reviews 6 371-382.

Félix B, Catalin D, Miolan JP \& Niel JP 2001 Effects of testosterone on the electrical properties and nicotinic transmission of the major pelvic and coeliac ganglion neurones. Journal of Neuroendocrinology 13 193-198.

Gejman PV \& Cardinali P 1983 Hormone effect on muscarinic cholinergic binding in bovine and rat sympathetic superior cervical ganglia. Life Sciences 32 965-972.

Gibori G, Khan I, Warshaw ML, McLean MP, Puryear TK, Nelson S, Durkee TJ, Azhar S, Steinschneider A \& Rao MC 1988 Placental-derived regulators and the complex control of luteal cell function. Recent Progress in Hormone Research $\mathbf{4 4}$ 377-429.

Goyeneche A, Calvo V, Gibori G \& Tellería C 2002 Androstenedione interferes in luteal regression by inhibiting apoptosis and stimulating progesterone production. Biology of Reproduction $\mathbf{6 6}$ 1540-1547.

Hammond J, Quynh LE, Goodyer C, Gelfand M, Trifiro M \& LeBlanc A 2001 Testosterone-mediated neuroprotection through the androgen receptor in human primary neurons. Journal of Neurochemistry $771319-1326$.

Hua SY \& Chen YZ 1989 Membrane receptor-mediated electrophysiological effects of glucocorticoid on mammalian neurons. Endocrinology 124 687-691.

Klein CM \& Burden HW 1988 Anatomical localization of afferent and postganglionic sympathetic neurons innervating the rat ovary. Neuroscience Letters 85 217-222.

Kotwica J, Bogacki M \& Rekawiecki R 2002 Neural regulation of the bovine corpus luteum. Domestic Animal Endocrinology 23 299-308.

Lawrence IEJ \& Burden HW 1980 The origin of the extrinsic adrenergic innervation to the rat ovary. Anatomic Records 196 51-55.

Lefkowitz RJ \& Caron MG 1987 Molecular and regulatory properties of adrenergic receptors. Recent Progress in Hormone Research 43 469-497.

Machelón V, Nomé F \& Tesarik J 1998 Nongenomic effects of androtenedione on human granulosa luteinizing cells. Journal of Clinical Endocrinology and Metabolism 83 263-269.

Matthews MR 1989 Small, intensely fluorescent cells and the paraneuron concept. Journal of Electronic Microscopic Technique $\mathbf{1 2}$ 408-416.

McEwen BS 1981 Neural gonadal steroid actions. Science 211 1303-1311.

McEwen BS \& Alves S 1999 Estrogen actions in the central nervous system. Endocrine Reviews 20 279-307.

Miszkiel G \& Kotwica J 2001 Mechanism of action of noradrenaline on the secretion of progesterone and oxytocin by the bovine corpus luteum in vitro. Acta Veterinaria Hungarica 49 39-51.

Morales MA, Holmberg K, Xu ZQ, Cozzari C, Hartman BK, Emson P, Goldstein M, Elfvin LG \& Hökfelt T 1995 Localization of choline acetyltransferase in rat peripheral sympathetic neurons and coexistence with nitric oxide syntase and neuropeptides. PNAS 92 819-825.

Papka RE \& Mowa CN 2003 Estrogen receptors in the spinal cord, sensory ganglia and pelvic autonomic ganglia. International Review of Cytology 231 91-125.

Pesta M, Muszynska A, Kucharski J, Superata J \& Kotwica J 1994 Beta-adrenergic receptors in corpora lutea from different stages of the estrous cycle in conscious and slaughtered cattle. Biology of Reproduction 50 215-221.

Prud'Homme MJ, Houdeau E, Serghini R, Tillet Y, Schemann M \& Rousseau JP 1999 Small intensely fluorescent cells of the rat 
paracervical ganglion synthesize adrenaline, receive afferent innervation from postganglionic cholinergic neurones, and contain muscarinic receptors. Brain Research 821 141-149.

Reynolds LP \& Ford SP 1984 Contractility of the ovarian vascular bed during the oestrous cycle and early pregnancy in gilts. Journal of Reproduction and Fertility 71 65-71.

Snedecor GW \& Cochram WG 1976 In Statistical Methods. Ames, IA: lowa State University Press.

Sosa ZY, Casais M, Rastrilla AM \& Aguado L 2000 Adrenergic influences on the coeliac ganglion affect the release of progesterone from cycling ovaries: characterisation of an in vitro system. Journal of Endocrinology 166 307-318.

Sosa ZY, Delgado M, Casais M, Aguado LI \& Rastrilla AM 2004 Release of ovarian progesterone during the rat oestrous cycle by ganglionic cholinergic influence. The role of NA. Journal of Steroid Biochemistry and Molecular Biology 91 179-184.

Sugino N, Tellería CM \& Gibori G 1997 Progesterone inhibits 20 $\alpha$ hydroxysteroid dehydrogenase expression in the rat corpus luteum through the glucocorticoid receptor. Endocrinology $\mathbf{1 3 8}$ 4497-4500.

Tellería CM, Stocco CO, Stati AO, Rastrilla AM, Carrizo DG, Aguado LI \& Deis RP 1995 Dual regulation of luteal progesterone production by androstenedione during spontaneous and RU486induced luteolysis in pregnant rats. Journal of Steroid Biochemistry and Molecular Biology 55 385-393.
Tellería CM, Stocco CO, Stati AO \& Deis RP 1999 Progesterone receptor is not required for progesterone action in the rat corpus luteum of pregnancy. Steroids 64 760-766.

Thordarson G, Galosy S, Gudmundsson GO, Newcomer B, Sridaran R \& Talamantes F 1997 Interaction of mouse placental lactogens and androgens in regulating progesterone release in cultured mouse luteal cells. Endocrinology 138 3236-3241.

Villavicencio A, Iñiguez G, Johnson MC, Gabler F, Palomino A \& Vega M 2002 Regulation of steroid synthesis and apoptosis by insulin-like growth factor I and insulin-like growth factor binding protein 3 in human corpus luteum during the midluteal phase. Reproduction 124501 -508.

Williams GL 1989 Modulation of luteal activity in post partum beef cows through changes in dietary lipid. Journal of Animal Science $67785-793$.

Woolley CS 1999 Effects of estrogen in the CNS. Current Opinion in Neurobiology 9 349-354.

Wright AF, Goedert M \& Hastie ND 1991 Familial Alzheimer's disease. Beta amyloid resurrected. Nature 349 653-654.

Received 21 June 2005

First decision 21 July 2005

Revised manuscript received 31 July 2005

Accepted 5 August 2005 